\title{
Development of a Rooted Cutting Propagation Method for Selected Arbutus unedo L. Types and Seasonal Variation in Rooting Capacity
}

\author{
M. Sulusoglu ${ }^{1}$ \\ ${ }^{1}$ Kocaeli University, Arslanbey Agricultural Vocational School, TR41285 Kocaeli, Turkey \\ Correspondance: M. Sulusoglu, Kocaeli University, Arslanbey Agricultural Vocational School, Kocaeli \\ TR41285, Turkey. E-mail: meleksl@kocaeli.edu.tr
}

Received: July 30, 2012 Accepted: August 13, 2012 Online Published: October 12, 2012

doi:10.5539/jas.v4n11p216 URL: http://dx.doi.org/10.5539/jas.v4n11p216

This study was supported by the Scientific Project Unit of Kocaeli University (project no: 2009/046)

\begin{abstract}
In this study, the rooting abilities of semi-hardwood cuttings from 8 Arbutus unedo L. (strawberry tree) types were evaluated. For this purpose, cuttings were taken at two different vegetation periods in July and November. The collected cuttings were treated with IBA $(2,4,6,8$ and $10 \mathrm{~g} / \mathrm{l})$ and placed into a misting system in July and bottom-heated system in November in the greenhouse. The rooting rate, survival rate and root quality were determined during the study. The cutting collection period significantly affected rooting ability, and according to the results obtained the best rooting performance was obtained with July cuttings except for types 1 and 8 . There were differences among the A. unedo L. types in rooting ability; Type 4 had the highest rooting rate $(87.01 \%$ in July and $70.71 \%$ in November) among the types studied. The percentage of rooted cuttings ranged from $0 \%$ to $100 \%$ for the control and IBA treatment for both periods and cuttings taken in November required higher concentrations of IBA for rooting than cuttings taken in July. The survival rate of cuttings varied according to type in the acclimatization stage, the best types being type 3 and type 4 . July cuttings of all types obtained shoots in the rooting media.
\end{abstract}

Keywords: Arbutus unedo L., strawberry tree, semi-hardwood cutting, IBA, rooting

\section{Introduction}

Arbutus unedo L. (strawberry tree) is an evergreen small tree or shrub largely found as a native in the Mediterranean region. The consumption of locally grown wild edible plants has been important for most human cultures, especially in the Mediterranean region, making an important contribution to the health of local communities (Heinrich, Müller, \& Galli, 2006). The Arbutus berries are also used for local vine production and other food applications Seidemann (1995); Pawlowska, De Leo, and Braca (2006); medicinal uses (Bnouham, Mekhfi, Legssyer, \& Ziyyat, 2002), landscaping and as a complement in the cut flower industry (Metaxas, Syros, Yupsanis, \& Economou, 2004). All populations, mainly near roads and coastlines, have been severely damaged due to deforestation and over-collecting for road-building studies during recent decades. Heterogeneity in the plantations is an important reason for the low-quality fruits and the edible use of the strawberry tree is currently limited. Restricted growing area and lack of commercial plantations leads to destruction of natural populations.

There are some studies to select good quality fruits for A. unedo L. (Songlin et al., 1995; Cai-Huang, 1997; Çelikel, Demirsoy, \& Demirsoy, 2008; Şeker, Akçal, Sakaldaş, \& Gündoğdu, 2010). Sulusoglu, Cavusoglu and Erkal (2011) evaluated pomological and chemical characteristics of 37 types of A. unedo L. in Samanli mountain locations in Marmara region of Turkey and according to the results; five types were selected as being superior. Vegetative propagation of these selected types is necessary to provide material for commercial use and orchard design and to reduce the natural habitat degradations. Generally $A$. unedo is characterized as a difficult-to-root plant (Hartmann, Kester, Davies, \& Geneve, 2002; Şeker, Akçal, Sakaldaş, \& Gündoğdu, 2010). Rooting of cuttings depends on the genotypes, age of the source tree, degree of hardening of the cuttings, injury and heat treatments of the cuttings, the collection date and the treatment concentrations of auxin-like compounds (Metaxas, Syros, Yupsanis, \& Economou, 2004; Pignatti \& Crabeddu, 2005); Metaxas, Syros, \& Economou, 2008; Şeker, Akçal, Sakaldaş, \& Gündoğdu, 2010). Among the Mediterranean scrubs, A. unedo is known for 
intensive activity in spring (Gratani \& Ghia, 2002) while in the Mediterranean climate a second period of growth starts with the first storm rains in August (Pignatti \& Crobeddu, 2005). This species bears fruit in late autumn and blossoms at the same time for the following year's fruits. Morphological and physiological characteristics of the stock plants at time of cutting collection affected the cutting rooting, and the optimal time for rooting should be established individually for each plant (Davies, 1984; Hansen, 1990; Howard, 1996; Klein, Cohen, \& Hebbe, 2000).

The primary objectives of this research were the evaluation of the rooting performance of the selected superior genotype and to clarify the importance of genotypes, concentration of auxin and cutting collection time on rooting of $A$. unedo $\mathrm{L}$. Thus the wild growing genetic material will be protected, an alternative fruit crop will be obtained for growers, and abundant high quality fruits will be supplied to consumers.

\section{Materials and Methods}

\subsection{Plant Material}

The investigations were conducted with the native grown A. unedo L. types selected in previous studies (Sulusoglu, Cavusoglu, \& Erkal, 2011) from the eastern part of the Marmara region in Samanli Mountain locations of Turkey. Some characteristics of types were given in Table 1. Semi hardwood cuttings were collected on the $10^{\text {th }}$ of July in 2010 and 2011 and $10^{\text {th }}$ of November in 2009 and 2010. Immediately after collection, the cuttings were cut into $15-\mathrm{cm}$ pieces and were cleaned from the leaves, leaving only a half leaf at the top portion of the cuttings. Then the cuttings were treated with a commercial fungicide (benomyl) by dipping in a liquid solution for 2 minutes. After surface drying, the bases of the cuttings were dipped for $10 \mathrm{~s}$ in one of five concentrations of IBA $(2,4,6,8$ and $10 \mathrm{~g} / 1 \mathrm{IBA})$, which is dissolved in a solvent composed of $50 \%$ ethanol and $50 \%$ tap water. The control cuttings were treated with the $50 \%$ ethanol only.

Table 1. Characteristics ${ }^{*}$ of cutting collected types

\begin{tabular}{|c|c|c|c|c|}
\hline & Fruit weight & $\operatorname{SSC}^{* *}(\%)$ & Total scores & Ranked \\
\hline Type 1 (Kİ3) ${ }^{*}$ & 4.10 & 24.03 & 190 & 23 \\
\hline Type $2(\mathrm{KI} 2)^{*}$ & 5.43 & 29.88 & 265 & 5 \\
\hline Type 3 (NM2) ${ }^{*}$ & 3.67 & 26.88 & 265 & 4 \\
\hline Type 4 UL2) ${ }^{*}$ & 2.06 & 22.75 & 135 & 37 \\
\hline Type 5 (NM1) ${ }^{*}$ & 2.67 & 31.00 & 165 & 30 \\
\hline Type 6 (UL1) ${ }^{*}$ & 6.46 & 27.08 & 285 & 1 \\
\hline Type 7 (ER1) ${ }^{*}$ & 5.89 & 26.00 & 275 & 2 \\
\hline Type 8 (YV3) ${ }^{*}$ & 5.42 & 30.03 & 270 & 3 \\
\hline
\end{tabular}

*Name of the types in Sulusoglu et al (2011)**Soluble solid content (\%)

\subsection{Rooting Medium and Rooting Conditions}

The cuttings were then planted in mist beds by inserting their bases about $5 \mathrm{~cm}$ into a rooting medium composed of perlite in an un-heated greenhouse. The cuttings were maintained in the system using an automatical fogging system (three minutes of fogging every hour during the lighted period) in July. The greenhouse had an evaporative cooling system (cooling pads and fan) to prevent the negative effects of high temperatures. In November the mist bed was covered with a polyethylene sheet for protection against the cold, and a bottom heating system was run. Additionally hydration was performed manually in this season.

Rooted cuttings were potted in a soil: turf: perlite (2:1:1) mix and irrigated regularly.

\subsection{Evaluations of Results}

The rooting process was monitored after the beginning of the experiments for the presence of callus, root and shoot. Cuttings were removed from rooting unit after 12 weeks for July cuttings and 15 weeks for November cuttings and rooting data was taken.

The experiment was conducted in a completely randomized plot design. Each treatment was comprised of an average of 30 cuttings (three replications of ten plants). Each experiment was repeated at least once. Rooting response (as rooting percentage, root number, root length), shoot and callus formation were measured. The arcsine 
square root transformation (Steel \& Torrie, 1960) was applied to the data to provide a normally distributed data set for the ANOVA. Data were subjected to ANOVA using Minitab Software (MINITAB Inc.) and the means were separated by Duncan's Multiple Range Test $(\mathrm{P} \leq 0.05)$.

\section{Results}

Types used in this experiment had large variations in rooting ability, with rooting percentages ranging from 0-100 percent according to IBA concentrations and cutting collection time. A significant interaction was observed between the cutting harvesting time and IBA concentrations for the all observed criteria.

Survival rates of type 1 cuttings were high in July but rooting rate, root length and root number were higher in November according to average values. Maximum rooting percentages were observed with $4 \mathrm{~g} / \mathrm{l}$ IBA concentrations in both cutting collection times. The longest roots $(3.12 \mathrm{~cm})$ were obtained with $4 \mathrm{~g} / 1 \mathrm{IBA}$ concentrations in November while the root number (5.67) was significantly increased with $8 \mathrm{~g} / \mathrm{l} \mathrm{IBA}$, again in November (Table 2). Callus formation was significantly high in November (Figure 1). Acclimatization rate was also better in cuttings to which was applied $8 \mathrm{~g} / \mathrm{l} \mathrm{IBA}$ for rooting in November (Figure 2) and this type displayed the lowest survival rate in the acclimatization stage.

Survival rates increased in July-collected cuttings of type 2. Type 2 needed high concentrations of IBA; the maximum rooting rate, root number and length were recorded in $8 \mathrm{~g} / 1 \mathrm{IBA}$ concentration in July and $10 \mathrm{~g} / \mathrm{lBA}$ concentration in November (Table 3). Cuttings rooted with these IBA concentrations also survived better in the acclimatization stage (Figure 2).

Survival rates of type 3 cuttings were significantly higher with $6 \mathrm{~g} / \mathrm{l}$ IBA concentration in July. At the end of the experiment the percentage of rooted control cuttings of type 3 reached $69.84 \%$ in July and this effect was statistically similar to the effects of IBA concentrations except $10 \mathrm{~g} / \mathrm{l}$ IBA. Increased concentrations of IBA negatively affected the rooting capacity; the lowest rooting rate was recorded with $10 \mathrm{~g} / \mathrm{l}$ IBA. November cuttings showed a different response to hormone concentrations and maximum rooting was recorded with $8 \mathrm{~g} / \mathrm{l}$ IBA concentrations (Table 4). In the acclimatization stage, the cutting survival rate was higher in July except for cuttings rooted with $8 \mathrm{~g} / \mathrm{l}$ IBA (Figure 2).

The best quality rooted and survived cuttings were taken from type 4. Rooting was observed in control cuttings at both cutting collection times. All cuttings treated with 8 and $10 \mathrm{~g} / 1$ IBA survived and rooted $(100 \%)$ in July (Table 5). Rooting was significantly increased with higher concentrations of IBA in July, while it decreased in November. It is shown that IBA concentration effects changed seasonally the rooting performance of $A$. unedo L. cuttings. The average root number was higher in November than in July and all IBA concentrations increased the root number in this time, the result being statistically important as well. Callus formation was very limited in July and November (Figure 1). Survival rates were quite high among the types in the acclimatization stage, and planted cutting numbers were at a satisfactory level (Figure 2).

Survival and rooting rates decreased with increasing concentrations of IBA in both cutting collection times (July and November) for type 5. Rooting was observed in untreated control cuttings in July. The best rooting was observed with $4 \mathrm{~g} / \mathrm{l}$ IBA-applied cuttings at July and November cutting collection times (Table 6). The longest $\operatorname{root}(9.88 \mathrm{~cm})$ was obtained with $10 \mathrm{~g} / 1$ IBA in July. A high amount of callus formation was observed in the July cuttings (Figure 1). The survival rate of July cuttings rooted with high concentrations of IBA was low in the acclimatization stage for this type of $A$. unedo L. (Figure 2).

In the case of type 6 cuttings, increasing concentrations of IBA caused the death of cuttings in July and this effect is statistically important as well. The maximum rooting was achieved with 4 and $6 \mathrm{~g} / 1 \mathrm{IBA}$ treated cuttings in July while untreated cuttings or cuttings treated with $10 \mathrm{~g} / 1$ IBA did not root. Rooting was achieved with high concentrations of IBA in November; rooting was observed in 8 and $10 \mathrm{~g} / 1$ IBA applied cuttings (Table 7). The survival rate was high for cuttings taken in July; only cuttings treated with $8 \mathrm{~g} / \mathrm{l}$ IBA could continue to growth after transfer to the acclimatization stage in November (Figure 2).

With all concentrations of IBA the cutting survival rate was higher in July than in November for type 7, but the highest rooting rate $(61.11 \%)$ was obtained with $8 \mathrm{~g} / \mathrm{l}$ IBA concentrations in November (Table 8). This concentration of IBA also increased the number of roots at significant rate (20 roots per cutting). Cuttings collected in July and rooted with $6 \mathrm{~g} / \mathrm{l}$ IBA fared better after transfer to the soil mixture in the acclimatization stage (Figure 2).

The proportion of type 8 cuttings that rooted was relatively high in November, compared to July. Only $4 \mathrm{~g} / \mathrm{lBA}$ obtained rooting in July but rooting percentages (18.89\%) and quality (root number is 3.25 and root length is $2.50 \mathrm{~cm}$ ) was very low so that November is the better time for cutting collection and rooting for this type (Table 
9). Cuttings collected in July did not develop any callus, while a very high level of callus was observed on cuttings collected in November (Figure 1). The survival rate was very low and all cuttings were dead after transfer for acclimatization except those rooted with $4 \mathrm{~g} / 1$ IBA in July and $6 \mathrm{~g} / 1$ IBA in November (Figure 2).

Table 2. Survival and rooting characteristics of type 1

\begin{tabular}{ccccccccc}
\hline & \multicolumn{2}{c}{ Survival (\%) } & \multicolumn{2}{c}{ Rooting (\%) } & \multicolumn{2}{c}{ Number of roots } & \multicolumn{2}{c}{ Root length (cm) } \\
\hline IBA & & & & & & & & \\
$(\mathrm{g} / \mathrm{l})$ & July & November & July & November & July & November & July & November \\
\hline 0 & $73.33 \mathrm{aA}$ & $10.00 \mathrm{bB}$ & $0.00 \mathrm{aA}$ & $0.00 \mathrm{bA}$ & $0.00 \mathrm{bA}$ & $0.00 \mathrm{dA}$ & $0.00 \mathrm{bA}$ & $0.00 \mathrm{dA}$ \\
2 & $80.00 \mathrm{aA}$ & $13.33 \mathrm{bB}$ & $0.00 \mathrm{aA}$ & $33.34 \mathrm{abA}$ & $0.00 \mathrm{bB}$ & $4.50 \mathrm{bA}$ & $0.00 \mathrm{bB}$ & $1.73 \mathrm{bA}$ \\
4 & $86.67 \mathrm{aA}$ & $16.67 \mathrm{abB}$ & $11.57 \mathrm{aA}$ & $44.44 \mathrm{aA}$ & $1.75 \mathrm{aB}$ & $3.00 \mathrm{cA}$ & $0.65 \mathrm{aB}$ & $3.12 \mathrm{aA}$ \\
6 & $36.67 \mathrm{bA}$ & $33.33 \mathrm{abA}$ & $0.00 \mathrm{aA}$ & $0.00 \mathrm{bA}$ & $0.00 \mathrm{bA}$ & $0.00 \mathrm{dA}$ & $0.00 \mathrm{bA}$ & $0.00 \mathrm{dA}$ \\
8 & $26.67 \mathrm{bA}$ & $40.00 \mathrm{aA}$ & $0.00 \mathrm{aA}$ & $26.11 \mathrm{aB}$ & $0.00 \mathrm{bB}$ & $5.67 \mathrm{aA}$ & $0.00 \mathrm{bB}$ & $1.50 \mathrm{cA}$ \\
10 & $20.00 \mathrm{bA}$ & $20.00 \mathrm{abA}$ & $0.00 \mathrm{aA}$ & $0.00 \mathrm{bA}$ & $0.00 \mathrm{bA}$ & $0.00 \mathrm{dA}$ & $0.00 \mathrm{bA}$ & $0.00 \mathrm{dA}$ \\
avg. & 53.89 & 22.22 & 1.93 & 17.32 & 0.29 & 2.20 & 0.11 & 1.06 \\
\hline
\end{tabular}

Table 3. Survival and rooting characteristics of type 2

\begin{tabular}{ccccccccc}
\hline \multicolumn{4}{c}{ Survival (\%) } & \multicolumn{2}{c}{ Rooting (\%) } & \multicolumn{2}{c}{ Number of roots } & \multicolumn{2}{c}{ Root length (cm) } \\
\hline $\begin{array}{c}\text { IBA } \\
(\mathrm{g} / \mathrm{l})\end{array}$ & \multicolumn{1}{c}{ July } & November & July & November & July & November & July & November \\
\hline 0 & $63.33 \mathrm{bcA}$ & $46.67 \mathrm{aA}$ & $0.00 \mathrm{cA}$ & $24.44 \mathrm{bB}$ & 0.00 & 1.25 & $0.00 \mathrm{dA}$ & $0.54 \mathrm{cA}$ \\
2 & $66.67 \mathrm{bcA}$ & $33.33 \mathrm{aB}$ & $30.16 \mathrm{bA}$ & $19.44 \mathrm{bA}$ & 2.61 & 1.00 & $0.79 \mathrm{cA}$ & $0.85 \mathrm{bA}$ \\
4 & $86.67 \mathrm{aA}$ & $43.33 \mathrm{aB}$ & $72.50 \mathrm{aA}$ & $27.78 \mathrm{abB}$ & 2.84 & 1.25 & $0.90 \mathrm{cA}$ & $0.68 \mathrm{bcA}$ \\
6 & $83.33 \mathrm{abA}$ & $50.00 \mathrm{aB}$ & $92.59 \mathrm{aA}$ & $42.22 \mathrm{abB}$ & 5.39 & 3.67 & $1.66 \mathrm{bA}$ & $1.70 \mathrm{aA}$ \\
8 & $93.33 \mathrm{aA}$ & $46.67 \mathrm{aB}$ & $92.50 \mathrm{aA}$ & $36.67 \mathrm{abB}$ & 6.45 & 4.50 & $2.28 \mathrm{aA}$ & $1.91 \mathrm{aA}$ \\
10 & $56.67 \mathrm{cA}$ & $60.00 \mathrm{aA}$ & $24.21 \mathrm{bA}$ & $61.27 \mathrm{aA}$ & 3.17 & 5.25 & $1.19 \mathrm{cB}$ & $1.93 \mathrm{aA}$ \\
avg. & 75.00 & 46.67 & 51.99 & 35.30 & 3.41 & 2.82 & 1.14 & 1.27 \\
\hline
\end{tabular}

Table 4. Survival and rooting characteristics of type3

\begin{tabular}{|c|c|c|c|c|c|c|c|c|}
\hline & \multicolumn{2}{|c|}{ Survival (\%) } & \multicolumn{2}{|c|}{ Rooting (\%) } & \multicolumn{2}{|c|}{ Number of roots } & \multicolumn{2}{|c|}{ Root length $(\mathrm{cm})$} \\
\hline $\begin{array}{l}\text { (BA } \\
(\mathrm{g} / \mathrm{l})\end{array}$ & July & November & July & November & July & November & July & November \\
\hline 0 & $76.67 \mathrm{bA}$ & $53.33 \mathrm{aB}$ & 69.84abA & $0.00 \mathrm{cB}$ & $4.94 \mathrm{bcA}$ & $0.00 \mathrm{bB}$ & $1.98 \mathrm{cA}$ & $0.00 \mathrm{bB}$ \\
\hline 2 & $86.67 \mathrm{bA}$ & $33.33 \mathrm{bB}$ & 76.85abA & $0.00 \mathrm{cB}$ & $5.14 \mathrm{bA}$ & $0.00 \mathrm{bB}$ & $3.94 \mathrm{aA}$ & $0.00 \mathrm{bB}$ \\
\hline 4 & $83.33 \mathrm{bA}$ & $60.00 \mathrm{aB}$ & 79.63abA & $12.22 \mathrm{bcB}$ & $7.82 \mathrm{aA}$ & $5.00 \mathrm{aB}$ & $4.38 \mathrm{aA}$ & $1.67 \mathrm{aB}$ \\
\hline 6 & $100 \mathrm{aA}$ & $33.33 \mathrm{bB}$ & $90.00 \mathrm{aA}$ & 19.44abB & $5.66 \mathrm{bA}$ & $4.50 \mathrm{aA}$ & $4.69 \mathrm{aA}$ & $1.67 \mathrm{aB}$ \\
\hline 8 & 76.6b7A & $36.67 \mathrm{bB}$ & $65.48 \mathrm{bA}$ & $36.11 \mathrm{aA}$ & $6.00 \mathrm{bA}$ & $4.67 \mathrm{aA}$ & $2.78 \mathrm{bA}$ & $2.39 \mathrm{aA}$ \\
\hline 10 & $53.33 \mathrm{cA}$ & $26.67 \mathrm{bB}$ & $20.95 \mathrm{cA}$ & $0.00 \mathrm{cB}$ & $3.50 \mathrm{cA}$ & $0.00 \mathrm{bB}$ & $1.67 \mathrm{cA}$ & $0.00 \mathrm{bB}$ \\
\hline avg. & 79.45 & 40.56 & 67.13 & 11.30 & 5.51 & 2.36 & 3.24 & 0.96 \\
\hline
\end{tabular}

Table 5. Survival and rooting characteristics of type 4

\begin{tabular}{cllllllll}
\hline \multicolumn{4}{c}{ Survival (\%) } & \multicolumn{2}{c}{ Rooting (\%) } & \multicolumn{2}{c}{ Number of roots } & \multicolumn{2}{c}{ Root length $(\mathrm{cm})$} \\
\hline IBA & & & & & & & & \\
$(\mathrm{g} / \mathrm{l})$ & \multicolumn{1}{c}{ July } & November & \multicolumn{1}{c}{ July } & November & July & November & July & November \\
\hline 0 & $83.33 \mathrm{bA}$ & $66.67 \mathrm{bB}$ & $51.85 \mathrm{cA}$ & $50.80 \mathrm{cA}$ & $3.23 \mathrm{cB}$ & $5.92 \mathrm{cA}$ & $4.01 \mathrm{abcB}$ & $9.99 \mathrm{aA}$ \\
2 & $86.67 \mathrm{bA}$ & $33.33 \mathrm{cB}$ & $80.56 \mathrm{bA}$ & $47.22 \mathrm{cB}$ & $3.97 \mathrm{cA}$ & $3.83 \mathrm{cA}$ & $2.16 \mathrm{cA}$ & $2.92 \mathrm{cA}$ \\
4 & $96.67 \mathrm{aA}$ & $83.33 \mathrm{aB}$ & $92.96 \mathrm{abA}$ & $84.13 \mathrm{abA}$ & $4.12 \mathrm{cB}$ & $11.88 \mathrm{bA}$ & $4.01 \mathrm{abcA}$ & $5.90 \mathrm{bA}$ \\
6 & $100 \mathrm{aA}$ & $90.00 \mathrm{aB}$ & $96.67 \mathrm{aA}$ & $92.96 \mathrm{aA}$ & $7.66 \mathrm{bB}$ & $20.33 \mathrm{aA}$ & $6.03 \mathrm{aA}$ & $4.42 \mathrm{bcA}$ \\
8 & $100 \mathrm{aA}$ & $66.67 \mathrm{bB}$ & $100 \mathrm{aA}$ & $80.82 \mathrm{abB}$ & $7.07 \mathrm{bB}$ & $13.96 \mathrm{bA}$ & $3.73 \mathrm{bcA}$ & $2.28 \mathrm{cA}$ \\
10 & $100 \mathrm{aA}$ & $43.33 \mathrm{cB}$ & $100 \mathrm{aA}$ & $68.33 \mathrm{bcB}$ & $13.03 \mathrm{aB}$ & $19.64 \mathrm{aA}$ & $4.75 \mathrm{abA}$ & $3.89 \mathrm{bcA}$ \\
avg. & 94.45 & 63.89 & 87.01 & 70.71 & 6.51 & 12.59 & 4.12 & 4.90 \\
\hline
\end{tabular}


Table 6. Survival and rooting characteristics of type 5

\begin{tabular}{|c|c|c|c|c|c|c|c|c|}
\hline & \multicolumn{2}{|c|}{ Survival (\%) } & \multicolumn{2}{|c|}{ Rooting (\%) } & \multicolumn{2}{|c|}{ Number of roots } & \multicolumn{2}{|c|}{ Root length $(\mathrm{cm})$} \\
\hline$(\mathrm{g} / \mathrm{l})$ & July & November & July & November & July & November & July & November \\
\hline 0 & $93.33 \mathrm{bA}$ & $33.33 \mathrm{bB}$ & $17.78 \mathrm{bA}$ & $0.00 \mathrm{cB}$ & $2.17 \mathrm{bcA}$ & $0.00 \mathrm{bB}$ & $3.65 \mathrm{cA}$ & $0.00 \mathrm{bB}$ \\
\hline 2 & 96.67abA & $33.33 \mathrm{bB}$ & $58.52 \mathrm{aA}$ & $0.00 \mathrm{cB}$ & $3.35 \mathrm{aA}$ & $0.00 \mathrm{bB}$ & $4.60 \mathrm{bA}$ & $0.00 \mathrm{bB}$ \\
\hline 4 & $100 \mathrm{aA}$ & 36.67abB & $63.33 \mathrm{aA}$ & $52.78 \mathrm{aA}$ & 2.94abB & $5.73 \mathrm{aA}$ & $1.43 \mathrm{dA}$ & $1.88 \mathrm{aA}$ \\
\hline 6 & $53.33 \mathrm{cA}$ & $53.33 \mathrm{aA}$ & $13.89 \mathrm{bA}$ & $24.44 \mathrm{bA}$ & $1.50 \mathrm{cB}$ & $5.67 \mathrm{aA}$ & $0.73 \mathrm{deB}$ & $2.03 \mathrm{aA}$ \\
\hline 8 & $46.67 \mathrm{cA}$ & 36.67abA & $0.00 \mathrm{cB}$ & $27.78 \mathrm{bA}$ & $0.00 \mathrm{~dB}$ & $4.00 \mathrm{aA}$ & $0.00 \mathrm{eB}$ & $1.24 \mathrm{aA}$ \\
\hline 10 & $53.33 \mathrm{cA}$ & $13.33 \mathrm{cB}$ & $20.84 \mathrm{bA}$ & $0.00 \mathrm{cB}$ & $1.50 \mathrm{cA}$ & $0.00 \mathrm{bB}$ & $9.88 \mathrm{aA}$ & $0.00 \mathrm{bB}$ \\
\hline avg. & 73.89 & 34.44 & 29.06 & 17.50 & 1.91 & 2.57 & 3.38 & 0.86 \\
\hline
\end{tabular}

Table 7. Survival and rooting characteristics of type 6

\begin{tabular}{cclllllll}
\hline \multicolumn{4}{c}{ Survival (\%) } & \multicolumn{2}{c}{ Rooting (\%) } & \multicolumn{2}{c}{ Number of roots } & \multicolumn{2}{c}{ Root length $(\mathrm{cm})$} \\
\hline IBA & & & & & & & \\
$(\mathrm{g} / \mathrm{l})$ & \multicolumn{1}{c}{ July } & November & \multicolumn{1}{c}{ July } & November & July & November & July & November \\
\hline 0 & $70.00 \mathrm{bA}$ & $15.00 \mathrm{bB}$ & $0.00 \mathrm{dA}$ & $0.00 \mathrm{bA}$ & $0.00 \mathrm{cA}$ & $0.00 \mathrm{cA}$ & $0.00 \mathrm{cA}$ & $0.00 \mathrm{bA}$ \\
2 & $73.33 \mathrm{bA}$ & $13.33 \mathrm{abB}$ & $63.69 \mathrm{cA}$ & $0.00 \mathrm{bB}$ & $3.38 \mathrm{bA}$ & $0.00 \mathrm{cB}$ & $2.34 \mathrm{bA}$ & $0.00 \mathrm{bB}$ \\
4 & $96.67 \mathrm{aA}$ & $20.00 \mathrm{abB}$ & $86.30 \mathrm{abA}$ & $0.00 \mathrm{bB}$ & $3.13 \mathrm{bA}$ & $0.00 \mathrm{cB}$ & $2.54 \mathrm{bA}$ & $0.00 \mathrm{bB}$ \\
6 & $93.33 \mathrm{aA}$ & $20.00 \mathrm{abB}$ & $96.29 \mathrm{aA}$ & $0.00 \mathrm{bB}$ & $4.83 \mathrm{abA}$ & $0.00 \mathrm{cB}$ & $3.74 \mathrm{aA}$ & $0.00 \mathrm{bB}$ \\
8 & $73.33 \mathrm{bA}$ & $36.67 \mathrm{aB}$ & $72.62 \mathrm{bcA}$ & $53.33 \mathrm{aA}$ & $4.88 \mathrm{aA}$ & $6.00 \mathrm{aA}$ & $3.90 \mathrm{aA}$ & $1.85 \mathrm{aB}$ \\
10 & $50.00 \mathrm{bA}$ & $20.00 \mathrm{abB}$ & $0.00 \mathrm{~dB}$ & $38.89 \mathrm{aA}$ & $0.00 \mathrm{cB}$ & $4.75 \mathrm{bA}$ & $0.00 \mathrm{cB}$ & $1.63 \mathrm{aA}$ \\
avg. & 76.11 & 20.83 & 53.15 & 15.37 & 2.70 & 1.79 & 2.09 & 0.58 \\
\hline
\end{tabular}

Table 8. Survival and rooting characteristics of type 7

\begin{tabular}{cclclllll}
\hline \multicolumn{4}{c}{ Survival (\%) } & \multicolumn{2}{c}{ Rooting (\%) } & \multicolumn{2}{c}{ Number of roots } & \multicolumn{2}{c}{ Root length $(\mathrm{cm})$} \\
\hline IBA & & & & & & & & \\
$(\mathrm{g} / \mathrm{l})$ & July & November & \multicolumn{1}{c}{ July } & November & July & November & July & November \\
\hline 0 & $63.33 \mathrm{aA}$ & $30.00 \mathrm{bB}$ & $21.43 \mathrm{aA}$ & $0.00 \mathrm{cB}$ & $1.17 \mathrm{abA}$ & $0.00 \mathrm{cA}$ & $3.13 \mathrm{aA}$ & $0.00 \mathrm{bB}$ \\
2 & $63.33 \mathrm{aA}$ & $56.67 \mathrm{aA}$ & $26.19 \mathrm{aA}$ & $0.00 \mathrm{cB}$ & $2.33 \mathrm{abA}$ & $0.00 \mathrm{cA}$ & $0.88 \mathrm{bA}$ & $0.00 \mathrm{bB}$ \\
4 & $66.67 \mathrm{aA}$ & $23.33 \mathrm{bB}$ & $30.16 \mathrm{aA}$ & $0.00 \mathrm{cB}$ & $3.00 \mathrm{aA}$ & $0.00 \mathrm{cB}$ & $1.02 \mathrm{bA}$ & $0.00 \mathrm{bB}$ \\
6 & $53.33 \mathrm{aA}$ & $33.33 \mathrm{bB}$ & $24.52 \mathrm{aB}$ & $38.89 \mathrm{bA}$ & $2.67 \mathrm{abB}$ & $10.17 \mathrm{bA}$ & $3.48 \mathrm{aA}$ & $3.46 \mathrm{aA}$ \\
8 & $53.33 \mathrm{aA}$ & $26.67 \mathrm{bB}$ & $0.00 \mathrm{bB}$ & $61.11 \mathrm{aA}$ & $0.00 \mathrm{bB}$ & $20.00 \mathrm{aA}$ & $0.00 \mathrm{cB}$ & $3.30 \mathrm{aA}$ \\
10 & $36.67 \mathrm{bA}$ & $23.33 \mathrm{bB}$ & $0.00 \mathrm{bA}$ & $0.00 \mathrm{cA}$ & $0.00 \mathrm{bA}$ & $0.00 \mathrm{cA}$ & $0.00 \mathrm{cA}$ & $0.00 \mathrm{bA}$ \\
avg. & 56.11 & 32.22 & 17.05 & 16.67 & 1.53 & 5.03 & 1.42 & 1.13 \\
\hline
\end{tabular}

Table 9. Survival and rooting characteristics of type 8

\begin{tabular}{cclclclll}
\hline \multicolumn{4}{c}{ Survival (\%) } & \multicolumn{2}{c}{ Rooting (\%) } & \multicolumn{2}{c}{ Number of roots } & \multicolumn{2}{c}{ Root length (cm) } \\
\hline $\begin{array}{c}\text { IBA } \\
(\mathrm{g} / \mathrm{l})\end{array}$ & \multicolumn{1}{c}{ July } & November & \multicolumn{1}{c}{ July } & November & July & November & July & November \\
\hline 0 & $33.33 \mathrm{bA}$ & $26.67 \mathrm{bA}$ & $0.00 \mathrm{bA}$ & $0.00 \mathrm{cA}$ & $0.00 \mathrm{bA}$ & $0.00 \mathrm{cA}$ & $0.00 \mathrm{bA}$ & $0.00 \mathrm{dA}$ \\
2 & $50.00 \mathrm{aA}$ & $33.33 \mathrm{abB}$ & $0.00 \mathrm{bA}$ & $0.00 \mathrm{cA}$ & $0.00 \mathrm{bA}$ & $0.00 \mathrm{cA}$ & $0.00 \mathrm{bA}$ & $0.00 \mathrm{dA}$ \\
4 & $53.33 \mathrm{aA}$ & $33.33 \mathrm{abB}$ & $18.89 \mathrm{aA}$ & $41.67 \mathrm{bA}$ & $3.25 \mathrm{aA}$ & $3.50 \mathrm{bA}$ & $2.50 \mathrm{aA}$ & $1.37 \mathrm{bB}$ \\
6 & $30.00 \mathrm{bA}$ & $40.00 \mathrm{aA}$ & $0.00 \mathrm{bB}$ & $60.56 \mathrm{aA}$ & $0.00 \mathrm{bB}$ & $8.56 \mathrm{aA}$ & $0.00 \mathrm{bB}$ & $2.00 \mathrm{aA}$ \\
8 & $33.33 \mathrm{bA}$ & $26.67 \mathrm{bA}$ & $0.00 \mathrm{bB}$ & $38.89 \mathrm{aA}$ & $0.00 \mathrm{bB}$ & $3.50 \mathrm{bA}$ & $0.00 \mathrm{bB}$ & $1.00 \mathrm{cA}$ \\
10 & $23.33 \mathrm{bA}$ & $23.33 \mathrm{bA}$ & $0.00 \mathrm{bA}$ & $0.00 \mathrm{cA}$ & $0.00 \mathrm{bA}$ & $0.00 \mathrm{cA}$ & $0.00 \mathrm{bA}$ & $0.00 \mathrm{dA}$ \\
avg. & 37.22 & 30.56 & 3.15 & 23.52 & 0.54 & 2.59 & 0.42 & 0.73 \\
\hline
\end{tabular}

*In table 2, 3, 4, 5, 6, 7, 8, and 9, values in the same column (IBA doses) with different lower-case letters and values in the same row (cutting collection time) with different capital letters are significantly different at $\mathrm{P} \leq 0.05$. 


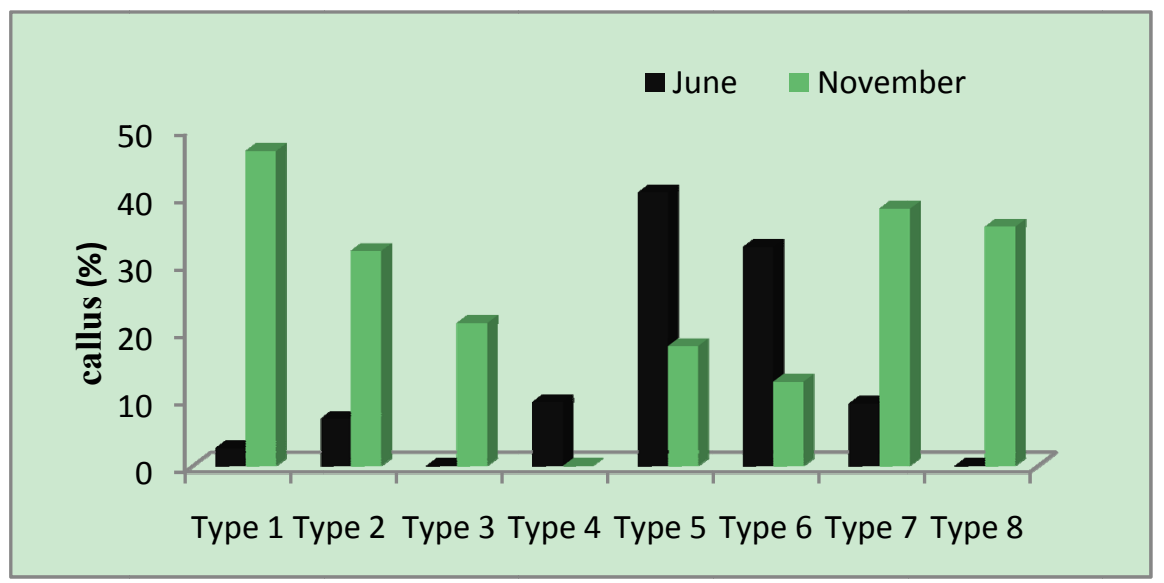

Figure 1. Callus formation of cuttings in July and November (average of IBA concentrations)

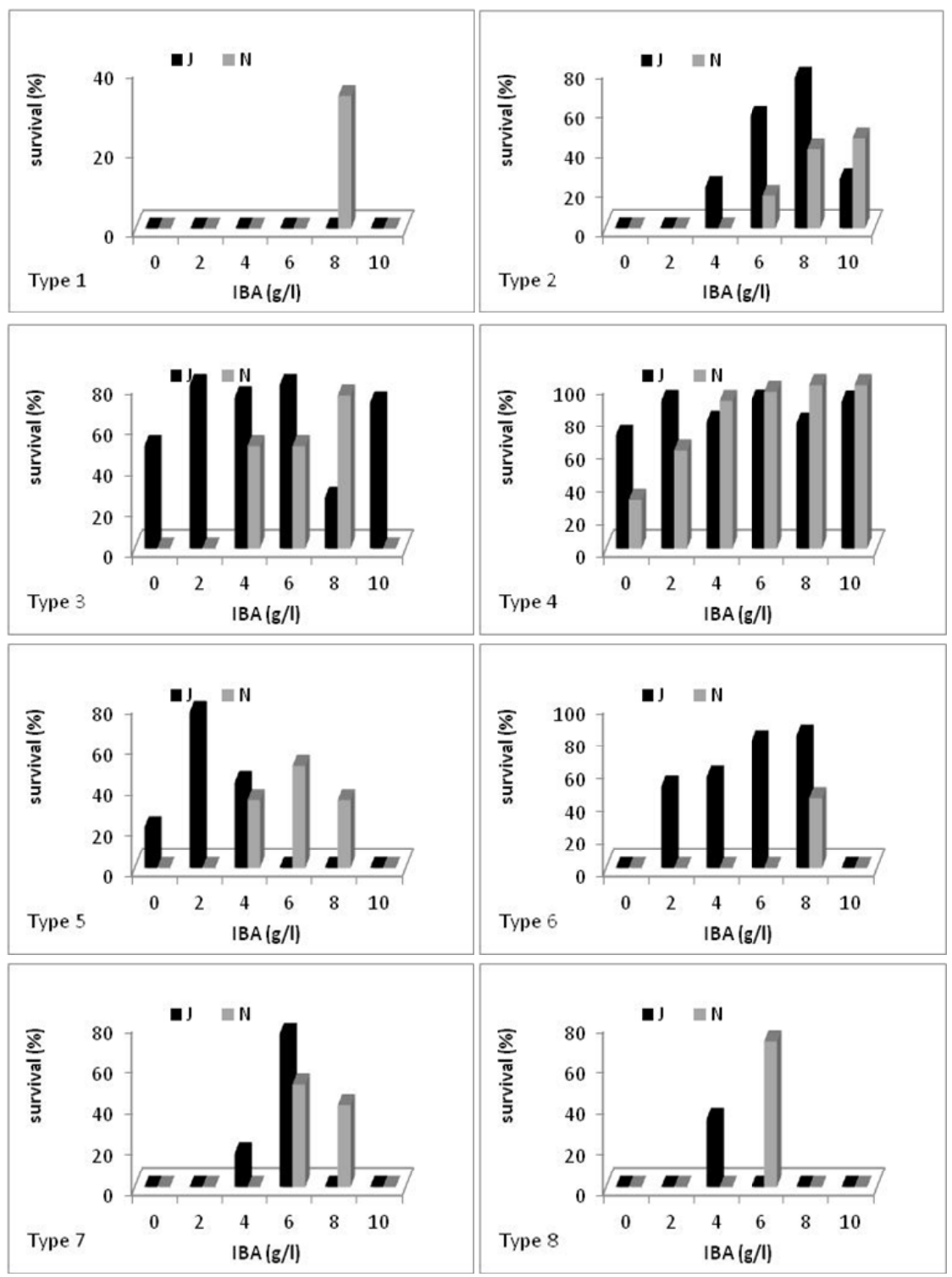

Figure 2. Survival of cuttings rooted in different IBA concentrations in acclimatization stage J: July, N: November 
In the rooting stage, shoot formation was observed on all types of cuttings. Type 4 formed a high amount of shoot formation while type 1 and 8 cuttings obtained much less shoot on the rooting media (Figure 3 ).

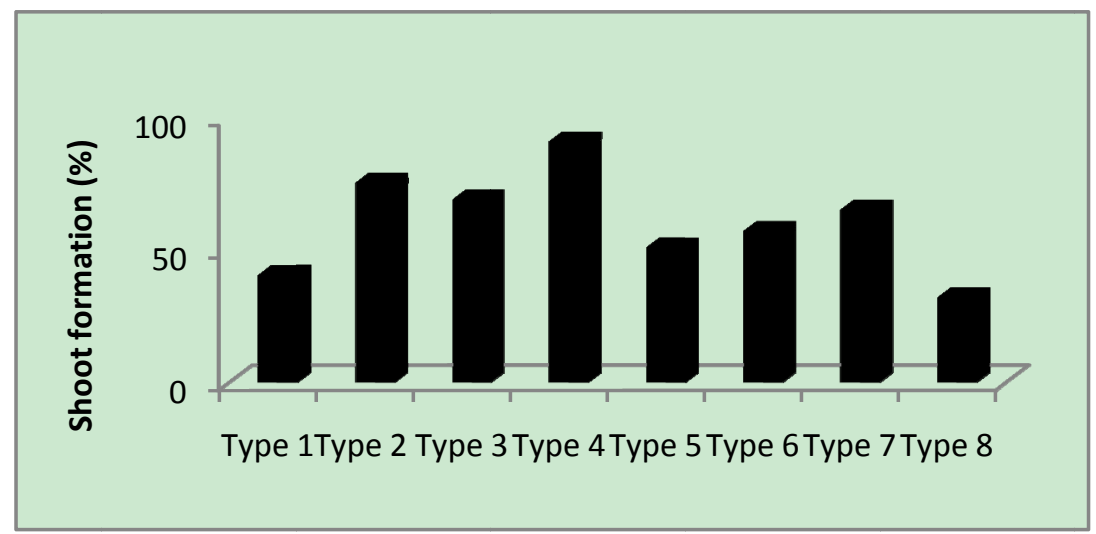

Figure 3. Shoot formation of cuttings in rooting media in July (average of concentrations)

\section{Discussion}

A.unedo L. types in some cases exceeded more than $50 \%$ rooting in this study. This percentage is considered the threshold value of economic convenience for mass production in nurseries (Hartmann, Kester, Davies, \& Geneve, 2002). The season of cutting collection exerted significant influences on the rooting of the A.unedo L. cuttings and had a remarkable effect on success in the acclimatization stage. July cuttings rooted better than November cuttings except for types 1 and 8 and these results are in agreement with similar studies. Metaxas, Syros, and Economou (2008) found that July and November were the best times to take cuttings for rooting and that the rooting rate was higher in July than November. Şeker, Akçal, Sakaldaş, and Gündoğdu (2010) reported that rooting rate and quality were better, again for July cuttings of A.unedo L.. These findings of a seasonal effect on rooting characteristics and field survival were in agreement with those of Hartmann and Loreti (1965), and of Brainerd and Evert (1980), who have reported that leafy semi-hardwood cuttings of indeciduous species root better during the summer season.

Genotype effect on rooting was highly evident in this research, a result consistent with results reported by Kester and Sartori (1966) and Sabbah, Grosser, Chandler and Louzada (1991) with almond and citrus. Therefore selection of source genotypes with a high propensity for rooting as well as for other favorable characters (high quality and productivity, disease resistance) is very important for successful commercial production of $A$. unedo L. Şeker, Akçal, Sakaldaş, and Gündoğdu (2010) reported that $A$. unedo L. is a difficult-to-root type while Metaxas, Syros, Yupsanis and Economou, 2004) had results similar to ours, namely that some genotypes of Arbutus showed high rooting performance while cuttings from some genotypes rooted at low percentages (varied between $22.2 \%$ and $94.1 \%$ ). In this study, type 4 rooted better and exhibited a higher field survival rate when compared to type 1 and 8 . It means that this type belongs to an easy-to-root category within the difficult root species A. unedo L. According to our results, types 2, 3 and 6 should be considered medium-level rooted and type 1, 5, 7 and 8 as bad-rooted types.

Application of auxin significantly improved rooting traits and auxin was essential for promoting root formation in difficult rooting types 1, 6 and 8 cuttings, which in the control treatments failed to produce any roots at either of the two cutting collection times. The same results have been reported in many plants capable of rooting (Sharma \& Aier, 1989; Tworkoski \& Takeda, 2007). Auxin is clearly involved in the root formation process, and the application of exogenously applied auxins can aid adventitious rooting (Saranga \& Cameron, 2007). Variations in response to auxin, even within one species, are common (Stankova \& Panetsos, 1997). Types 1 and 8 showed very limited rooting percentages with all IBA concentrations. It could be said that the genetical rooting capacity is limited and IBA is not suitable for the rooting protocol of these types. Type 8 especially was determined as a promising type in the selection studies (Sulusoglu, Cavusoglu, \& Erkal, 2011) and needs to improve rooting capacity. Metaxas, Syros, and Economo (2008) improved the rooting capacity of A. unedo L. types with K-IBA treatment. Sebastiani, Tognetti, Di Paolo, and Vitagliano (2002) managed to increase the rooting of olive cuttings with the addition of hydrogen peroxide to the IBA treatment. Further improvement in rooting induction of these types could probably be obtained with different treatments. 
Successful rooting is determined not only by rooting percentage, but also by the number of roots formed and root length (Rugini, Di Francesco, Muganu, Astolfi, \& Caricato, 1997; Hartmann, Kester, Davies, \& Geneve, 2002; Metaxas, Syros, \& Economou, 2008). In this study type 4 formed well-rooted cuttings which formed directly from the stem greater numbers of adventitious primary roots suitable for commercial situations. Types 1 and 8 generated only one single or a few root formations and were often discarded due to the promotion of a weak and one-sided root system. Placing the cutting back in the propagation environment may encourage a more robust root system, and hence a stronger plant (Saranga \& Cameron, 2007). In future studies this could be tried to increase root formation and quality. Well-rooted cuttings succeeded better in the acclimatization stage after transfer to greenhouse conditions and with this technique it will be possible to increase rooting quality of cuttings.

Besides the number of parameters that determine physiological status of mother plant and cuttings, the meteorological conditions in the months preceding sampling of cuttings or in the year before are also important factors. This difference in growing conditions of donor plants could bias to some extent the results of the study (Hartmann, Kester, Davies, \& Geneve, 2002). In the present study, the poor or good rooting performance and acclimatization of $A$. unedo $\mathrm{L}$. types must also be attributed to their physiological conditions or anatomical characteristics in addition to their genetic constitution. Karadeniz, Kalkışım, and Şişman (2003), could not obtained rooted A. unedo L. cuttings in any treatments of IBA. Şeker, Akçal, Sakaldaş, and Gündoğdu (2010), obtained the highest rooting percentage with $6 \mathrm{~g} / \mathrm{l}$ IBA treatment in July cuttings, although the rooting rate was lower than our results. In spite of the fact that they could not observe rooting in control cuttings, in this research rooting was obtained with control cuttings of types $2,3,4,5$ and 7 . With difficult-to-root species rooting can be enhanced when the use of supportive propagation environment allows cuttings to survive long enough to enable adventitious root formation to take place before tissue viability is lost (Howard \& Harrison-Murray, 1995). In our experiment, fogging and a bottom-heated system also increased rooting success. Forcing the cutting in a bottom-heated greenhouse in winter is essential for rapid production of $A$. unedo $\mathrm{L}$.

\section{Conclusions}

According to results of this study, cutting collection time and concentration of IBA had a significantly high impact on $A$. unedo L. cutting survival and rooting. In general, high overall levels of rooting were obtained with 4 or $6 \mathrm{~g} / \mathrm{IBA}$, while generally a 90-100 day period was required for $A$. unedo L. cuttings to root. The vegetative buds of the rooted cuttings began to grow 4-5 weeks after planting in July; most of the rooted cuttings grew into complete plants and it could be suggested that if appropriate source genotypes are used, a commercially useful level of plant material production for commercial orchards may be obtained.

Rooting capacity of cuttings varied considerably according to the type. The rooting rate of the selected superior types was lower than that of less edible types having a small fruits. Rooting capacity needs to improve for these types, or alternative propagation techniques for commercial production, such as grafting or in vitro propagation, can be tried. Well-rooted types such as type 4 could be tried as a rootstock for grafting treatments as well.

\section{References}

Brainerd, K. E., \& Evert, D. R. (1980). Rooting of Forsythia softwood cuttings. Plant Propagator, 26, 13-15. Retrieved from www.cabdirect.org/.../19800385758.html

Bnouham, M., Mekhfi, H., Legssyer, A., \& Ziyyat, A. (2002). Ethnopharmacology forum medicinal plants used in the treatment of diabetes in Morocco. Int. J. of Diabetes and Metabolism, 10, 33-50.

Cai-Huang, C. H. (1997). The cultural practices for high and top quality production of Arbutus fruit trees. China Fruits, 3, 48.

Celikel, G., Demirsoy, L., \& Demirsoy, H. (2008). The strawberry tree (A.unedo L.) selection in Turkey. Sci. Hortic., 118, 115-119.

Davies, F. T. (1984). Shoot RNA, cambial activity and indolebutyric acid effectivity in seasonal rooting of juvenile and mature Ficus pumila cuttings. Physiologia Plantarum, 62, 571-575. http://dx.doi.org/10.1111/j.1399-3054.1984.tb02801.x

Gratani, L., \& Ghia, E. (2002). Changes in morphological and physiological traits during leaf expansion of Arbutus unedo. Environmental and Experimental Botany, 48, 51-60.

Hartmann, H. T., Kester, D. E., Davies, F. T., \& Geneve, R. L. (2002). Plant Propagation: Principles and Practices (7th ed.). Prentice Hall Publishers, 880.

Hartmann, H. T., \& Loreti, F. (1965). Seasonal variation in rooting leafy olive cuttings under mist. Proceedings of 
the American Society for Horticultural Science, 87, 194-198.

Hansen, O. B. (1990). Rapid production of apple rootstocks by softwood cuttings. Scientia Hortic., 42, $277-287$.

Heinrich, M., Müller, W. E., \& Galli, C. (2006). Local Mediterranean food plants and nutraceuticals. Forum of Nutrition Basel Karger, 59, 18-74.

Howard, B. H., \& Harrison-Murray, R. S. (1995). Responses of dark-preconditioned and normal light-grown cuttings of Syringa vulgaris 2 Madame Lemoine 2 to light and wetness gradients in the propagation environment. J. Hort. Sci., 70, 989-1001.

Howard, B. H. (1996). Relationships between shoot growth and rooting of cuttings in three contrasting species of ornamental shrub. J. of Hort. Sci., 71, 345-351.

Karadeniz, T., Kalkışım, Ö., \& Şişman, T. (2003). Trabzon çevresinde yetişen kocayemiş (Arbutus unedo L.) tiplerinin meyve özellikleri ve çelikle çoğaltılması. Ulusal Kivi ve Üzümsü Meyveler Sempozyumu, 23-25, 476-480.

Kester, D. E., \& Sartori, E. (1966). Rooting of cuttings in populations of peach (Prunus persica L.) and almond (Prunus amygdalus Batsch) and their F1 hybrids. Proc. Am. Soc. Hort. Sci., 88, 219-223.

Klein, J. D., Cohen, S., \& Hebbe, Y. (2000). Seasonal variation in rooting ability of myrtle (Myrtus communis L.) cuttings. Scientia Horticulturae, 83, 71-76.

Metaxas, D., Syros, T. D., Yupsanis, T., \& Economou, A. S. (2004). Peroxidases during adventitious rooting in cuttings of Arbutus unedo and Taxus baccata as affected by plant genotype and growth regulator treatment. Plant Growth Regulation, 44, 257-266.

Metaxas, D., Syros, T., \& Economou, A. (2008). Factors affecting vegetative propagation of Arbutus unedo L. by stem cuttings. Propagation of Ornamental Plants, 8, 190-197.

Pawlowska, A. M., De Leo, M., \& Braca, A. (2006). Phenolics of Arbutus unedo L. (Ericaceae) Fruits: Identification of anthocyanins and gallic acid derivates. J. of Agricultural and Food Chemistry, 54(26), 10234-10238.

Pignatti, G., \& Crobeddu, S. (2005). Effects of rejuvenation on cutting propagation of Mediterranean shrub species. Forest, 2(3), 290-295.

Rugini, E., Di Francesco, G., Muganu, M., Astolfi, S., \& Caricato, G. (1997). The effects of polymines and hydrogen peroxide on root formation in olive and the role of polyamines as an early marker for rooting ability. In: Altman, A. Waisel, Y. (Editors), Biology of Root Formation and Develoment (pp. 65-73). New York, NY: Plenum Pres.

Sabah, S. M., Grosser, J. W., Chandler, J. L., \& Louzada, E. S. (1991). The effect of growth regulators on the rooting of stem cuttings of citrus, related genera and intergeneric somatic hybrids. Proc. Fla. State Hort. Soc., 104, 188-191.

Saranga, J., \& Cameron, R. (2007). Adventitious root formation in Anacardium occidentale L. İn response to phytohormones and removal of roots. Scientia Horticulturae, 111, 164-172.

Sebastiani, L., Tognetti, R., Di Paolo, P., \& Vitagliano, C. (2002). Hydrogen peroxide and indole-3-butyric acid effects on root induction and development in cuttings of Olea europaea L. (cv Frontoio and Gentile di Larino). Adv. Hort. Sci., 1, 7-12.

Seidemann, J. (1995). Knowledge of little-known exotic fruits. 5. strawberry tree (Arbutus unedo L.). Deutsche Lebensmittel Rundschau, 91(4), 110-113.

Sharma, S. D., \& Aier, N. B. (1989). Seasonal rooting behaviour of cuttings of plum cultivars as influenced by IBA Treatments. Scientia Horticulturae, 40, 297-303. http://dx.doi.org/10.1016/0304-4238(89)90103-9

Songlin, M., Yuejian, Z., Senmiao, L., Huang, X. G., Wang, S. F., Miao, S. L., ... Liang, S. M. (1995). Zaose, a promising new Arbutus cultivar. China Fruits, 4, 3-4.

Stankova, T., \& Panetsos, K. (1997). Vegetative propagation of Cupressus sempervirens L. of Cretan origin by softwood stem cuttings. Silvae Genetica, 46, 137-144.

Steel, R., \& Torrie, J. H. (1960). Principles and Procedures of Statistics (p. 481). New York, NY: McGraw-Hill Book Co. Inc.

Sulusoglu, M., Cavusoglu, A., \& Erkal, S. (2011). Arbutus unedo L. (Strawberry tree) selection in Turkey 
Samanli mountain locations. J. of Medicinal Plants Research, 5(15), 3545-3551.

Şeker, M., Akçal, A., Sakaldaş, M., \& Gündoğdu, M. A. (2010). Effects of different periods and auxins concentrations on rooting ability of Strawberry Tree (Arbutus unedo L.) cuttings. U.Ü. Ziraat Fak. Dergisi, 24(1), 99-108.

Tworkoski, T., \& Takeda, F. (2007). Rooting response of shoot cuttings from three peach growth habits. Scientia Horticulturae, 115, 98-100. 